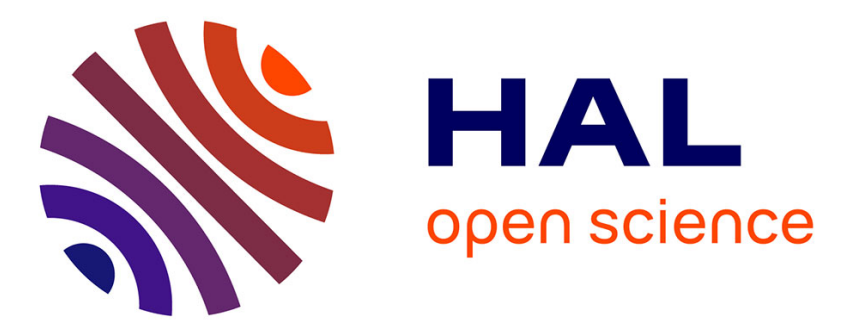

\title{
Cattle manure for biogas production. Does ensiling and wheat straw addition enhance preservation of biomass and methane potential?
}

\author{
Ruben Teixeira Franco, Pierre Buffière, Rémy Bayard
}

\section{- To cite this version:}

Ruben Teixeira Franco, Pierre Buffière, Rémy Bayard. Cattle manure for biogas production. Does ensiling and wheat straw addition enhance preservation of biomass and methane potential?. Biofuels, 2017, pp.1 - 12. 10.1080/17597269.2017.1387751 . hal-01692799

\section{HAL Id: hal-01692799 \\ https://hal.science/hal-01692799}

Submitted on 25 Jan 2018

HAL is a multi-disciplinary open access archive for the deposit and dissemination of scientific research documents, whether they are published or not. The documents may come from teaching and research institutions in France or abroad, or from public or private research centers.
L'archive ouverte pluridisciplinaire HAL, est destinée au dépôt et à la diffusion de documents scientifiques de niveau recherche, publiés ou non, émanant des établissements d'enseignement et de recherche français ou étrangers, des laboratoires publics ou privés. 


\title{
Cattle manure for biogas production. Does ensiling and wheat straw addition
} enhance preservation of biomass and methane potential?

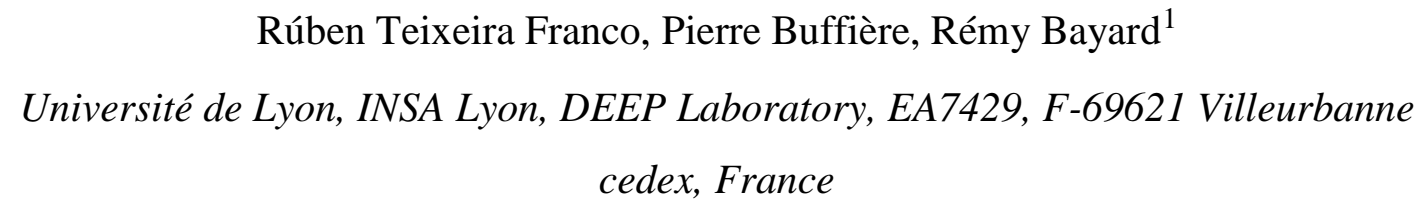

\begin{abstract}
The effects of ensiling and open-air storage on the conservation of cattle manure were investigated for 120 days at laboratory scale. Impact of co-ensiling with wheat straw was assessed as well. Up to $74 \%$ of methane potential was lost during aerobic storage. Negligible energetic losses and ammonia emissions occurred during the first month of anaerobic preservation. However, inadequate chemical properties of fresh cattle manure hindered silage stabilization for extended periods, leading to $46 \%$ of methane losses after 4 months. Co-ensiling of cattle manure with wheat straw enhanced biomass acidification, inducing a conservation of more than $86 \%$ of the methane potential after 4 months. Wheat straw addition suppressed ammonia production and limited the risks of losses through liquid effluent. The current study proves that long-term conservation of cattle manure can be achieved if correct management practices are used, which will undoubtedly improve the performance of biogas plants with this raw material.
\end{abstract}

Keywords: Cattle manure; Storage; Ensiling; Anaerobic digestion; Methane potential

${ }^{1}$ Corresponding author. Tel.: +33(0) 472438753

E-mail addresses: ruben.teixeirafranco@insa-lyon.fr (R. Teixeira Franco), pierre.buffiere@insa-lyon.fr (P. Buffière), remy.bayard@insa-lyon.fr (R. Bayard) 
- Ensiling enhanced biomass and methane conservation of cattle manure

- Ammonia emissions during storage are minimized through ensiling

- Co-ensiling with wheat straw stabilized biomass at elevated $\mathrm{pH}$ value

- Wheat straw addition minimized risk of losses through effluent production

- Silage with wheat straw conserved at least $86 \%$ of methane potential after 4 months

\section{Abbreviations}

AA, acetic acid; AD, anaerobic digestion; ADF, acid detergent fiber; ADL, acid detergent lignin; BA, butyric acid; BMP, biochemical methane potential; CEL, cellulose; HEM, hemicellulose; LA, lactic acid; LAB, lactic acid bacteria; LIG, lignin; $\mathrm{NDF}$, neutral detergent fiber; $\mathrm{NH}_{3}-\mathrm{N}$, ammonia nitrogen; TKN, total Kjeldahl nitrogen; TS, total solids; VS, volatile solids; WSC, water soluble carbohydrates; VFA; volatile fatty acids

\section{Introduction}

Several European countries are currently mobilizing for the energy recovery from cattle manure through anaerobic digestion (AD). In France, the annual production of cattle manure is estimated at nearly $87 \mathrm{Mt}$, which represents around 28.3 MWh of potential primary energy [1]. Nevertheless, due to its production fluctuations and in order to enable a continuous supply of biogas plants throughout the year, cattle manure needs to be stored before use, in some cases for extended periods. For this feedstock, a common practice is the open-air storage before AD. The reason for this is mainly related to the simplicity and low cost of the operation. However, this practice has several drawbacks. Generally speaking, air presence is perceived as a spoiling agent for biomass conservation, leading to important energy losses during long-term storage with aerobic spoilage of easily biodegradable organic fraction. Recent works with different catch 
crops showed that more than $80 \%$ of biochemical methane potential (BMP) was lost after 3 months of storage in the presence of air [2,3]. In the specific case of cattle manure, this reality is further compounded by the fact that open-air storage facilities are important sources of ammonia and odor emissions [4].

Regarding conservation methods before $\mathrm{AD}$, ensiling is usually pointed out as the logical choice to store wet biomass. This process is typically divided into four phases, based on different biochemical transformations [5-8]. Right after filling and sealing the silo, biomass respiration occurs due to the presence of oxygen trapped in the system. Once oxygen has been depleted, ensiling passes to an anaerobic fermentation phase. If the conditions are suitable, lactic acid bacteria (LAB) will produce lactate from available carbohydrates for several weeks, decreasing the $\mathrm{pH}$ to around 4.0. Maintaining anaerobic conditions and a relatively low $\mathrm{pH}$, minimal enzymatic and microbial activity occur until feed-out. After unloading the silo for $\mathrm{AD}$ feeding, biomass enters once again into aerobic environment, which may spoil the silage. While well succeeded, ensiling enhances biomass conservation and minimize energy losses. For instance, Herrmann $e t$ al. [9] observed an average of $2 \%$ difference between BMP of fresh and ensiled material after 1-year ensiling of maize, sorghum hybrid, forage rye and triticale.

Given the high efficiency of ensiling for other biomass crops, it should be expectable to obtain good preservation of cattle manure using the same method. However, ensiling success is extremely dependent on several biochemical characteristics of feedstock, such as moisture content, water-soluble carbohydrates (WSC) content, buffering capacity and endogenous microflora [6,7]. Indeed, cattle manure does not fulfill the chemical requirements for an efficient ensiling, especially due its lack of WSC. Without 
those, organic acids cannot be produced in a significant extent and then, the desired level of acidity for silage stabilization would not be achieved.

Even if cattle manure does not naturally lead to an optimal ensiling conservation, it is possible that an anaerobic environment reduces organic matter and energy losses during storage. Furthermore, efficiency of cattle manure ensiling may be improved by costorage with wheat straw. In fact, this co-substrate is considered to have an impact on organic losses of traditional crops ensiling [6]. This may be related to the fact that straw addition decreases the moisture content and microbial concentration of the feedstock. Therefore, straw may act as a delaying agent of bacterial growth, improving energy conservation during storage. Likewise, wheat straw addition to cattle manure should decrease soluble organic matter concentration on the feedstock, which may facilitate silo compaction and prevent energy losses through leachate formation during storage. However, to the best of our knowledge, no study addressing these subjects exists today.

81 This work established a comparison between open-air storage and ensiling of cattle manure during 120 days at laboratory scale. The effects of different degrees of wheat straw addition on silage conservation were also addressed. Storage performance was evaluated, above all, by its impact on BMP conservation of raw material. Notwithstanding, other parameters, such as organic matter losses or eventual gas emissions, were examined during storage as well. This study contributes to the optimization of practices for cattle manure management before biogas production, which will definitively have an impact on the energy recovered downstream. 


\section{Material and methods}

\subsection{Substrates}

Fresh cattle manure was collected on 10 March 2016 from an agricultural site in the Rhône-Alpes region of France (Gaec Béreyziat, Les Teppes, 01340 Béréziat, France) and it was stored at $4{ }^{\circ} \mathrm{C}$ before further use. Fresh raw material had $13 \%$ of total solids (TS) content and it was tested in both aerobic and ensiling conditions. In addition, two mixtures of fresh cattle manure and wheat straw were prepared at the laboratory and tested for ensiling. Wheat straw had $10 \mathrm{~cm}$ maximum length and it was mixed with cattle manure in order to achieve final TS contents of $19 \%$ and $22 \%$, respectively. Storage conditions and description of respective raw materials are summarized in Table 1.TS13\%E and TS13\%A represent the ensiling and open-air storage of fresh cattle manure, respectively. TS19\%E corresponds to the co-ensiling of cattle manure and straw with final TS content of $19 \%$. TS22\% $\mathrm{E}$ is related to the co-ensiling of cattle manure and straw with final TS content of $22 \%$.

\section{2. $\quad$ Storage approach}

Laboratory trials were performed in $3.5 \mathrm{~L}$ airtight round plastic storage drums. In order to enable the output of the gas produced and at the same time minimizing headspace, silos were filled up to $2.55 \mathrm{~L}$ with raw material at packing density of $0.7 \mathrm{~kg} / \mathrm{L}$, the remaining volume being filled with gravel, using a geotextile membrane to separate it from biomass. Silo sealing was different depending on the storage method tested. For ensiling assays, proper plastic lid and rubber ring were used and its airtightness was reinforced with silicone sealant. For aerobic storage purposes no cover was used and silo was left air-open. Then, silos were weighed and placed in a controlled-temperature 
113 (4 operating conditions $\mathrm{x} 4$ storage durations) conservation assays were done.

\subsection{Chemical analysis}

For each sample time, one silo (per tested condition) was sacrificed. It was opened and weighed, biomass was homogenized and two samples were taken. One was used for direct analyses on the crude material and the other one was mixed with water in order to get two fractions: a water-soluble phase and a particulate phase. This leaching test was performed with a 10:1 water/TS ratio during $2 \mathrm{~h}$ under constant bottle rotation. Phase separation was achieved by centrifugation $(5000 \mathrm{G} ; 10 \mathrm{~min}$ ) followed by $0.7 \mu \mathrm{m}$ particle size filtration. Finally, the particulate phase was dried at $70{ }^{\circ} \mathrm{C}$ until constant weight and ground at $2 \mathrm{~mm}$ theoretical length. Crude material/water-soluble and particulate samples were stored at $4{ }^{\circ} \mathrm{C}$ and $-20{ }^{\circ} \mathrm{C}$, respectively, until use.

Crude material was analyzed for its TS content, volatile solids (VS) content and BMP. For the water-soluble phase, besides TS/VS content and BMP, $\mathrm{pH}$, WSC, volatile fatty acids (VFA), total Kjeldahl nitrogen (TKN) and ammonia nitrogen $\left(\mathrm{NH}_{3}-\mathrm{N}\right)$ fractions were determined. Particulate solid was analyzed for its TS/VS, TKN and cell wall constituents content.

TS was measured by oven drying at $105^{\circ} \mathrm{C}$ during $24 \mathrm{~h}$ and VS was subsequently burned for $2 \mathrm{~h}$ at $550{ }^{\circ} \mathrm{C}$. Since TS/VS contents are underestimated due to the loss of volatile compounds during the drying tests [10], the measures were corrected using the volatilization coefficients at $100{ }^{\circ} \mathrm{C}$ suggested by Porter and Murray [11]. $\mathrm{pH}$ was measured by a Consort C3020 device with a SP10B pH-electrode. WSC, lactic acid and formic acid contents were determined with high performance liquid chromatography 
135 (LC Module 1 plus, Waters) equipped with a Supelcogel ${ }^{\mathrm{TM}} \mathrm{C}-610 \mathrm{H}$ column $(300 \times 7.8$

$136 \mathrm{~mm}$, Sigma-Aldrich), both refractive index (RID) and UV detectors and operating with

$137 \mathrm{H}_{3} \mathrm{PO}_{4} 0.1 \% \mathrm{v}$ as solvent (flow rate of $0.5 \mathrm{~mL} / \mathrm{min}$ ). WSC content was estimated as the

138 sum of glucose, xylose, galactose, mannose, arabinose and cellobiose and was

139 determined using the UV detector $(210 \mathrm{~nm})$. Lactic acid and formic acid contents were

140 obtained with the RID detector. Acetic, propionic, butyric, valeric and caproic acids

141 content were analyzed using gas chromatography (Shimadzu Corp.) equipped with a

142 HP-FFAP fused silica capillary column (30 m x $0.25 \mathrm{~mm}$, Agilent Technologies), a

143 flame ionization detector and using $\mathrm{H}_{2}$ as carrier gas. Total VFA was calculated as the

144 sum of lactic, formic, acetic, propionic, butyric, valeric and caproic acids. Neutral

145 detergent fiber (NDF), acid detergent fiber (ADF) and acid detergent lignin (ADL) were

146 analyzed through Van Soest and Wine [12] modified extractions method, based on XP

147 U44-162 French standard. Hemicellulose content (HEM) was calculated as NDF minus

148 ADF; cellulose (CEL) as ADF minus ADL and; lignin (LIG) as approximatively equal

149 to $\mathrm{ADL}$. TKN and $\mathrm{NH}_{3}-\mathrm{N}$ were determined through the procedure described in the $\mathrm{NF}$

150 EN 25663 French standard.

151 The interest of our experimental procedure is to enable the assessment of the

152 composition and BMP based on the initial mass of product used, since the weight loss

153 was measured. The results for the chemical analysis will thus be presented in two ways:

154 based on $\% \mathrm{VS}_{\text {added }}$ or $\% \mathrm{VS}_{\text {original. }} \mathrm{VS}_{\text {added }}$ relates to the organic matter of the sample

155 analyzed. The results based on VS original take into account the loss of volatile solids

156 during storage and allows the study of the results based on the VS of the initial material. 


\subsection{Biochemical methane potential tests}

158 Batch anaerobic digestion tests were performed for crude material and water-soluble 159 phase samples. Tests were conducted in a temperate room at $35^{\circ} \mathrm{C}$ using glass vessels 160 of $2 \mathrm{~L}$ for crude material and $0.1 \mathrm{~L}$ for water-soluble phase. Vessels were filled with $5 \mathrm{~g}$

161 VS of sample, inoculum in way to keep a substrate/inoculum VS ratio of 0.5 and a certain volume of a mineral solution to achieve $60 \%$ of the total volume of the vessel. The inoculum used (TS 3.0-3.2\%wt; VS 2.0-2.2\%wt) was a digested sludge originating from the wastewater treatment plant of La Feyssine, Lyon, France. The mineral solution, which contains essential elements to microbial growth and also gives the solution a buffer able to control any $\mathrm{pH}$ adjustments, was prepared according to the recommendations of ISO 11734:1995 standard. Once filled, reactors were purged with a $\mathrm{N}_{2} / \mathrm{CO}_{2}$ mixture $(80 / 20 \% \mathrm{v})$ for about 5 minutes, sealed and equilibrated at $35{ }^{\circ} \mathrm{C}$.

Blanks with only inoculum and mineral solution were performed for each batch series in order to correct the BMP from residual methane production of the inoculum. All tests were performed in triplicates.

Biogas production was determined by pressure measurement using a Digitron precision manometer. Biogas was released when the pressure exceeded $1200 \mathrm{hPa}$. Gas composition was analyzed using an Agilent 3000 micro gas chromatography with thermal conductivity detector (GC-TCD). Molsieve 5A (14 m length; pore size: $5 \AA$ ) and PoraPlot A (10 m length; $0.320 \mathrm{~mm}$ ID) columns were used as stationary phases for

177 GC-TCD, with Argon and Helium as carrier gases, respectively. Biogas production and considered achieved when daily vessel overpressure of controls equalized the sample ones. The BMP tests followed the recommendations provided by Holliger et al. [13]. 
181 In order to assess the kinetics of methane production, the experimental data of BMP

182

183

184

185

186

187

188

189

190

191

192

193

194

195

196

197

198

199

200

201

202

203 assays was fitted to the following equation:

$$
V_{C H_{4}}(t)=V_{\max }\left(1-e^{-k t}\right)
$$

Where, $V_{\mathrm{CH}_{4}}$ corresponds to the volume of methane produced; $t$ is the time of the assay; $V_{\max }$ is the maximum volume of methane produced, which was equivalent to the experimental BMP value and; $k$ is the rate coefficient of $\mathrm{CH}_{4}$ production. Since gas production started almost immediately after reactors were sealed, lag time was not considered in the calculations.

\section{Results and discussion}

\subsection{Feedstock characterization}

Chemical characteristics of raw materials and stored biomass are presented in Table 2. Besides low TS content (12.8\%), fresh cattle manure was mainly characterized by a negligible content of WSC and $\mathrm{pH}$ value of 7.9. These were unsuitable features for energy conservation through an acidification-based process as ensiling. First of all, as lower TS crops are more unstable and susceptible to deterioration, lower silage $\mathrm{pH}$ is required for an efficient ensiling [6]. By analogy with the data published by Kalač [14] for ensiled forage, a critical $\mathrm{pH}$ value of around 4.0 is required to preserve fresh cattle manure. In order to achieve such degree of acidification, extensive production of lactic acid should occur in the first days of ensiling [6]. However this would require an adequate level of readily available carbohydrates, i.e. high WSC content. In fresh cattle manure, energy sources were mainly concentrated in the form of lignocellulosic compounds. Indeed, cellulose and hemicellulose contents of fresh cattle manure were estimated as 26.8 and $32.5 \%$ of organic matter, respectively. Nevertheless, it should not 

biochemical accessibility is rather limited by lignin protection (6.1\%VS) [15] and extent.

Structure of cell wall constituents changed with wheat straw addition to cattle manure. This was, in fact, the only remarkable effect of wheat straw beyond the increase of TS/VS content. Cellulose content increased to 36.0-37.2\%VS after wheat straw addition. In turn, hemicellulose content decreased to 27.5-28.7\%VS. No noticeable effect on lignin content was recorded with wheat straw addition.

\subsection{Effects of storage method on biomass preservation}

\subsubsection{Chemical characteristics}

215 Aerobic storage was mainly characterized by a $\mathrm{pH}$ increase and modifications on organic matter structure, Table 2 . Structural carbohydrates were uninterruptedly degraded along the 4 months, culminating in both cellulose and hemicellulose losses of around $60 \%$ of their initial content. Furthermore, no accumulation of WSC nor VFA was recorded for this condition. This suggests that the degradation of structural carbohydrates led to severe VS and energy losses. Lignin content did not vary significantly, meaning that no (or limited) delignification occurred during aerobic storage. In addition to these chemical modifications, fungi development was noticeable throughout open-air storage. Therefore, microbial degradation must have occurred

224 through an aerobic metabolism producing carbon dioxide and microbial biomass.

225 Storage in anaerobic conditions of fresh cattle manure led to VFA production and $\mathrm{pH}$ decrease until 30 days. Nevertheless, the acidification was slow since only structural carbohydrates were available for fermentation. This should explain the significant 
reduction of (hemi-) cellulose content during the first month of ensiling. The major components of VFA were acetic and butyric acid, with other small fractions of propionic, valeric and caproic acid. No formation of lactic acid was detected during ensiling. Since the fermentation products of TS13\%E are weaker acids than lactic acid, $\mathrm{pH}$ drop for stored cattle manure was not as marked as in lactate silages. In addition, between 14 days and 30 days of ensiling, VFA content increased from $6.0 \%$ to $12.9 \% \mathrm{VS}_{\text {added }}$ but $\mathrm{pH}$ value remained stable at 6.9. This evidenced that fresh cattle manure had a strong buffer capacity at neutral $\mathrm{pH}$ conditions. Altogether, efficient $\mathrm{pH}$ values around 4.0 were not achieved for ensiling of fresh cattle manure and further biomass degradation occurred for prolonged storage periods. Indeed, between 30 and 120 days, fermentation profile reversed and more than 90\% of VFA were consumed until the end of storage. This caused an increase of $\mathrm{pH}$, which reached a value of 8.4 at 120 days. The fact that this $\mathrm{pH}$ value were superior to the one of the raw material can be explained by the ammonia production and accumulation during ensiling. Moreover, structural carbohydrates continued to be degraded until the end of the storage. After 4 months, $48 \%$ and $37 \%$ of original hemicellulose and cellulose were biodegraded, respectively. Thus, non-negligible organic matter and energy losses must have occurred for long-term ensiling of fresh cattle manure.

Equivalent fermentation profiles were found for TS13\% E and co-ensiling conditions in the first month of storage. However, the rate of acidogenesis decreased with wheat straw addition. This may be explained by the fact that wheat straw mostly contains hardly accessible carbohydrates. Moreover, wheat straw addition has decreased the initial microbial concentration and moisture content, which delayed bacterial growth. For instance, it is well known that at least part of silage bacteria have lower activity for 
higher TS contents $[6,16,17]$. Nevertheless, wheat straw addition enhanced stability of cattle manure silages. For both TS19\%E and TS22\%E, pH value decreased from 8.2-8.3 before storage to around 5.5-5.6 after 30 days and remained constant until 4 months of ensiling. Additionally, even if VFA production was more restricted for co-ensiling, fermentation had a much higher impact on silage acidification than in TS13\%E. This suggests that wheat straw addition reduced the buffer capacity of the raw material at neutral $\mathrm{pH}$ value. Despite the apparent stability of wheat straw silages, degradation of structural carbohydrates occurred until the end of the storage. After 4 months, $28 \%$ and $29 \%$ of the sum of original (hemi-) cellulosic compounds were missing for TS19\%E and TS22\%E, respectively. However, this should not have led to substantial energy losses, since VFA accumulation occurred until the end of storage for both co-silages.

The data presented here evidenced that the recommended $\mathrm{pH}$ value of around 4.10-4.35 for TS content between 15-25\% [14] was not applicable for the conservation of cattle manure, or at least for its co-ensiling with wheat straw. It must be remembered that this value of $\mathrm{pH}$ is the required acidity to prevent lactate degradation. In our experiments, no lactate was produced during ensiling. This means that either lactic acid was quickly consumed as an intermediate for acidogenesis, or that monosaccharides were degraded by other pathways than LAB fermentation. In any case, the stability of cattle manure did not relied on lactic acid formation but on the accumulation of VFA during storage.

Therefore, the critical $\mathrm{pH}$ in cattle manure silages should be considered as the required acidity to prevent methanogenic activity and further VFA damage for long-term storage, which was achieved for both TS19\%E and TS22\%E conditions. 


\subsubsection{TKN balance}

Effects of storage method on total Kjeldahl nitrogen balance are presented in Figure 1.

277 This evolution is related to the TKN content of feedstocks, which was $4.0 \% \mathrm{VS}$ for fresh 278 cattle manure, $2.7 \% \mathrm{VS}$ for TS19\% $\mathrm{E}$ and $2.3 \% \mathrm{VS}$ for TS22\% $\mathrm{E}$.

279

Regarding open-air storage, there was a continuous elimination of TKN, resulting in losses of $58.6 \%$ of its original content after 120 days. Mechanisms of degradation can be suggested through analysis of TKN composition along storage. First, there was a considerable decrease of particulate TKN content, which ranged from 52\% to $39 \%$ of original TKN during the 4 months of aerobic treatment. Major part of particulate loss occurred during the first 7 days of storage, during which the content of the watersoluble phase of organic nitrogen increased. This indicates that some proteins were subject to hydrolysis under aerobic conditions, therefore increasing the amount of organic nitrogen compounds that can be processed by microorganisms capable of nitrogen mineralization and nitrate/nitrite production. However this may only partially explain the original source of TKN losses, due to the limited degradation extent of organic nitrogen in the particulate phase during storage. In fact, the majority of structural modifications of TKN during aerobic treatment occurred in the water-soluble phase. From 7 days of storage and until the end of conservation, the content of organic nitrogen in the liquid fraction decreased, which suggests that the rate of amino acid degradation was significant during aerobic treatment. Even if the previous mechanisms may lead to inorganic nitrogen production, this was not observed during storage. Indeed, ammonia concentration decreased all along storage duration, from $1.30 \% \mathrm{VS}_{\text {original }}$ before storage to $0.02 \% \mathrm{VS}_{\text {original }}$ after 120 days of aerobic treatment. This may be explained by the constant perturbations in the $\mathrm{NH}_{4}{ }^{+} / \mathrm{NH}_{3}$ equilibrium $\left(\mathrm{pK}_{\mathrm{a}}\right.$ 
$299=9.25)$ during conservation. In open-air storage, $\mathrm{NH}_{3}$ emissions did not have any

300 impact on its concentration in the gas phase, since ammonia produced was instantly

301 diluted in the atmosphere. Thus, in such conditions, nitrogen was considered to be lost

302 through $\mathrm{NH}_{3}$ production, even at relatively low $\mathrm{pH}$. The rate of ammonia loss improved

303 with time, as $\mathrm{pH}$ increased for long periods of aerobic treatment. Furthermore,

304 nitrification reactions may have contributed to the elimination of organic nitrogen in

305 aerobic conditions. This would lead to nitrate and nitrite emissions, which are not

306 measured in the TKN procedure. Considering that all TKN losses led to ammonia

307 emissions, around $40.1 \mathrm{~L}_{\mathrm{NH} 3} / \mathrm{kgVS}_{\text {original }}$ were expected to be released into the

308 atmosphere during the 4 months of open-air storage of fresh cattle manure.

309 Ammonia emissions were reduced through ensiling of fresh cattle manure. Indeed, in

310 the first 30 days of ensiling there was a complete preservation of TKN content and at

311 the end of storage only $12 \%$ of its original content was lost. This latter value

312 corresponded to a theoretical value of $9.0 \mathrm{~L}_{\mathrm{NH} 3} / \mathrm{kgVS}$ original for gas emissions during the

3134 months of ensiling. Nevertheless, there was a larger transformation of TKN structure

314 for ensiling than for open-air storage. On the one hand, the organic nitrogen content in

315 both particulate and water-soluble phase decreased almost linearly with time, from a

316 total $68 \% \mathrm{TKN}_{\text {original }}$ before storage to $35 \% \mathrm{TKN}_{\text {original }}$ after 4 months. On the other hand,

317 ammonia content clearly increased along ensiling. In such conditions, TKN degradation

318 must have occurred through two successive reaction mechanisms: hydrolysis of proteins

319 into amino acids and subsequent fermentation in ammonia. These are typical reactional

320 mechanisms that arise during anaerobic fermentation [18] and poor silages (high $\mathrm{pH}$

321 values) [6]. Besides $\mathrm{NH}_{4}{ }^{+}$, these reactions generally lead to other side-products, such as

322 a pool of organic acids, $\mathrm{CO}_{2}$ and $\mathrm{H}_{2}$, generating energy losses, regardless of how small 
323 they may be. Even if there is a high production of ammonia during ensiling, gas

324 emissions should be avoided as long as the silo is airtight and a low $\mathrm{pH}$ medium is

325 present. This explain why degraded nitrogen was stored under the form of $\mathrm{NH}_{4}{ }^{+}$in the

326 first month of ensiling. However, during the last 3 months of storage, $\mathrm{pH}$ increased to

327 values near the $\mathrm{pK}_{\mathrm{a}}$ of $\mathrm{NH}_{4}{ }^{+} / \mathrm{NH}_{3}$, which led to TKN losses through ammonia

328 production.

329 Co-ensiling of cattle manure with wheat straw did not have a significant impact on the 330 reactional mechanisms related to TKN. However, lower degradation rates of TKN were 331 obtained for TS19\%E and TS22\%E. In fact, organic nitrogen content (from both particulate and water-soluble phases) was around 70\% TKN for all three feedstocks. This amount decreased to $34.8 \% \mathrm{TKN}_{\text {original }}$ for TS13\%E, $41.4 \% \mathrm{TKN}_{\text {original }}$ for $\mathrm{TS} 19 \% \mathrm{E}$ and $51.9 \% \mathrm{TKN}_{\text {original }}$ for $\mathrm{TS} 22 \% \mathrm{E}$ at the end of storage. These results may be in part linked to the effect of lower growth of proteolytic clostridia for higher TS contents, which has been reported in the literature for other types of silages $[6,19,20]$. Nitrogen losses were even lower than in $\mathrm{TS} 13 \% \mathrm{E}$ condition, reaching at the most $2.3 \% \mathrm{TKN}_{\text {original }}$ during the co-ensiling. This corresponded to theoretical ammonia emissions of 1.2 $\mathrm{L}_{\mathrm{NH} 3} / \mathrm{kgVS}$ original at the end of the storage. Enhanced conservation of nitrogen was related to the stable low $\mathrm{pH}$ value obtained during the 4 months for silages with wheat 341 straw.

\subsubsection{Organic matter losses}

343 Higher damage of organic matter was found for the aerobic treatment, as shown in

344 Figure 2. After one month, around $25 \%$ of organic matter of open-air stored cattle 345 manure was lost, which ascended to more than $50 \%$ after 4 months. This was linked to 346 the constant loss of structural polymers during storage. 
347 Silage quality had an important effect on VS conservation during storage. Anaerobic 348 storage of fresh cattle manure limited the organic losses to less than $10 \%$ in the first 349 month, the period in which there was an accumulation of VFA. Nevertheless, silage 350 instability of low TS crop aforementioned led to damage of almost $40 \%$ of original VS 351 content at the end of the 4 months.

352 Co-ensiling with wheat straw had a positive effect on organic matter conservation. For TS19\%E and TS22\%E, most part of the VS losses occurred in the first month and corresponded to $5 \%$ of original VS. During this period, $\mathrm{pH}$ kept decreasing. Therefore, other bacteria populations capable of VS degradation, such as methanogens, must have proliferated under such conditions. Furthermore, fermentation of monosaccharides may lead to several side-products. For instance, reactional mechanisms of acetate or butyrate production include $\mathrm{CO}_{2}$ and $\mathrm{H}_{2}$ formation. Besides organic matter damaging, this would cause slight energy losses, as hydrogen would be lost into the environment during silo opening. In addition, nitrogen mineralization contributed to VS losses, although to a minor extent. During the last 3 months of storage, organic matter suffered minimal damage, due to silage stabilization. After 4 months, $92 \%$ of original VS was conserved for both co-storage conditions. These are remarkable results regarding silage conservation, since they are equivalent $[3,9]$ or even better $[2,21,22]$ than data found in the literature concerning good quality of crop silage. All things considered, there was a positive effect on the conservation of the biomass inherent to the wheat straw addition. This is in agreement with McDonald et al. [6], who considered straw as an additive for ensiling, due in part to its effect on the reduction of organic matter losses. 


\subsection{Effects of storage method on methane potential}

\subsubsection{BMP evolution}

372 Evolution of methane potential along storage is presented in Figure 3. The results exposed are related to both $\mathrm{VS}_{\text {original }}$ and $\mathrm{VS}_{\text {added, }}$, which allows the monitoring of original BMP conservation and eventual modifications on the chemical accessibility of the remaining biomass. BMP of aerobic treatment $(\mathrm{TS} 13 \% \mathrm{~A})$ ranged from $288 \mathrm{~L} / \mathrm{kgVS}$ before storage to $157 \mathrm{~L} / \mathrm{kgVS}_{\text {added }}$ and $74 \mathrm{~L} / \mathrm{kgVS}_{\text {original }}$ after 4 months. BMP losses were divided in two distinct chronologic phases. Around half of energetic damage occurred during the first month of storage. This was expected since in first moments of long-term storage, besides the particulate phase, the major part of soluble organic matter should be within reach of aerobic microorganism. In this period, losses followed a linear tendency, equivalent to $1.2 \%$ original BMP loss per day. Methane potential losses slowed down somewhere between the second and fourth month and led to $74 \%$ of BMP lost at the end of aerobic storage.

Energy conservation was improved with ensiling of fresh cattle manure (TS\%13E), since constantly higher BMP values during storage were obtained rather than when aerobic assays were carried out. As in the preceding condition, two chronologic phases of BMP evolution were observed for TS13\%E. A slight BMP increase was found during the first weeks of storage for low TS silage. Indeed, after 1 month of storage original methane potential was improved by $11 \%$, which is substantially higher than the limit of accuracy of BMP tests. Enhanced biochemical accessibility of feedstock must have been the source of this energetic increment, as BMP related to VS added varied from 288 to 348 $\mathrm{L} / \mathrm{kgVS}_{\text {added }}$ during the first month. As previously discussed, during this period, production and accumulation of VFA took place through degradation of (hemi-) 
cellulosic compounds. These latter polymers are not fully biodegradable in such soft condition as that experienced within the mesophilic AD process [23]. Therefore, their hydrolysis/acidogenesis during ensiling is a reasonable explanation for the BMP increase. This trend did not last until the end of storage, since in the last 3 months BMP of fresh ensiled cattle manure abruptly decreased, either considering organic matter losses or not. Consequently, TS13\%E lost $46 \%$ of its original methane potential after the end of the 4 months of storage. One can assume that this energetic loss was linked to the consumption of VFA and structural carbohydrates during this period of storage.

In order to evaluate the tradeoff between higher energy conservation rates during ensiling and cost increase by silo construction, a financial estimation was performed. For silo construction, a medium practiced cost in France of $40 € / \mathrm{m}^{3}(57 € /$ ton for a packing density of $0.7 \mathrm{~kg} / \mathrm{m}^{3}$ ) was used. Likewise, a reference value in France of 80 $€ / \mathrm{MWh}$ was applied to the purchase price of additional bio-methane produced. Taking corresponds to around $6.3 € /$ ton of additional revenue by ensiling batch. Therefore, the investment made in silo construction should be recovered after 3 years (considering 3 storage batches per year). Is important to notice that the real recovery period should be estimation.

Wheat straw addition had a positive effect on BMP conservation of cattle manure during ensiling in the long term. In fact, minor variations were recorded on the methane

417 potential along the 4 months of storage for both conditions using straw: TS19\%E 
418 showed BMP values of 277-304 L/kgVS added and 271-287 L/kgVS original; while for

419 TS22\%E it were observed 285-321 L/kgVS ${ }_{\text {added }}$ and $265-305 \mathrm{~L} / \mathrm{kgVS}_{\text {original. }}$. Although

420 less clear than in previous storage conditions, BMP evolution during storage of both

421 TS19\%E and TS22\%E can be separated in two periods of time. After one month of

422 storage, BMP related to $\mathrm{VS}_{\text {added }}$ increased by about $10 \%$ and $4 \%$ for $\mathrm{TS} 19 \% \mathrm{E}$ and

423 TS22\%E conditions, respectively. This reflects a slight enhancement of biochemical

424 accessibility of raw materials and it should be interrelated with the production and

425 accumulation of VFA in silage from hardly biodegradable carbohydrates during this

426 period. Nevertheless, this effect was counteracted by organic matter losses.

427 Consequently, the improvement of BMP related to original VS was not relevant (within

428 the precision limits). Between the end of the first and fourth month, BMP related to

$429 \mathrm{VS}_{\text {added }}$ decreased by $3 \%$ for TS19\% $\mathrm{E}$ and $11 \%$ for TS22\%E. This evidenced that

430 biodegradability of stabilized silages may decrease in long-term storage, which may

431 arise since the so-called biomass stabilization occurred at relatively high $\mathrm{pH}$ values. At

432 the end of the 4 months of ensiling, $98 \%$ and $86 \%$ of feedstock's methane potential was

433 conserved for TS19\%E and TS22\%E, respectively. This proves that wheat straw

434 addition was in both cases an asset to BMP preservation for long-term ensiling of cattle

435 manure and that use of $19 \%$ TS should lead to optimal energy recovery. Furthermore,

436 using the same parameters of the preceding financial estimation, higher energy

437 conservation rates of TS19\%E and TS22\%E (compared to open-air storage) should lead

438 to $25.7 € /$ ton and $23.9 € /$ ton of additional income per storage batch. This indicates that

439 the investment for silo construction should be covered in less than 1 year for efficient

440 ensiling conditions. The price of wheat straw was not included in these calculations,

441 since its energy potential should be recovered in methane production. 
442 Finally, our results suggest that there is a strong correlation between fermentation

443 profiles, organic matter conservation and BMP for prolonged storage durations. At the

444 same time, one may take into account that BMP assays may last for about 2 to 3 months

445 to be completed. Therefore, whenever either a quick analysis of several storage

446 conditions is required or only simple approaches are available, organic matter losses

447 determination (e.g., or even total weight loss) may be a resourceful method for

448 qualitative analysis on optimization of storage conditions for a specific feedstock before

449 biogas production.

450 3.3.2. BMP distribution in particulate and water-soluble phase

451 The contribution of the soluble and particulate fraction to the total BMP is presented on

452 Figure 4. During aerobic storage (TS13\%A) the water-soluble contribution of BMP

453 varied from $27 \%$ before storage to $10 \%$ after 4 months. Furthermore, nearly all the

454 water-soluble contribution decreased during the first month of storage. This observation

455 supports the hypothesis earlier debated that higher rate of BMP losses observed during

456 the first weeks of open-air storage was a consequence of the degradation of water-

457 soluble compounds.

Minor changes on BMP contributions (between particulate and soluble part) were detected for ensiling of fresh cattle manure (TS13\%E) during the first month of storage,

460 with water-soluble phase representing $25-32 \%$ of total methane potential. Significant degradation of water-soluble phase only occurred during the last 3 months, decreasing its fraction to $15 \%$ of total BMP at the end of storage. These results partially agree with the data afore discussed. On the one hand, a clear increase tendency of water-soluble

464 phase of BMP was expected over the first month of ensiling. This would be the result of 465 the increase of VS soluble fraction along storage duration, which was indeed recorded 
either by direct measure of VS fractions (result not shown) or by degradation of

467 structural carbohydrates and VFA accumulation. On the other hand, the decrease of water-soluble fraction of BMP in the last 3 months of storage is in line with the loss of almost the totality of VFA that was observed during this period.

Analogous evolutions of BMP fractions during ensiling were observed for both degrees of wheat straw addition. For instance, regarding TS19\%E condition, water-soluble fraction of BMP increased from $19 \%$ prior to storage to $34 \%$ after 4 months. This is in agreement with data from fermentation profiles, and confirms that complex energy sources have not only been degraded but also solubilized and conserved in that form for prolonged periods of ensiling. However, this mechanism of energy conservation may not be applicable to all types of cattle manure. In fact, bacterial populations can be influenced by the characteristics of manure [24], which may depend on the type of cattle, animal's diet, as well as, on the time of the year [25]. Therefore, for several types of manures, the methanogens concentration, e.g., may be far superior to the one of the feedstock used in these tests. In such cases, solubilization of particulate would still occur but VFA produced would be degraded due to a higher methanogenic activity. This will weaken ensiling efficiency, as it will lead to substantial energy losses before $\mathrm{AD}$.

Moreover, wheat straw addition had an impact on BMP distribution before storage: water-soluble phase of BMP decreased from $25 \%$ for TS13\% E (and TS13\%A) to $20 \%$ and $19 \%$ for TS19\%E and TS22\%E, respectively. This was expected since organic matter of wheat straw is mostly under particulate form. Nevertheless, these are promising results for ensiling low TS feedstocks. In field scale silage of standard crops, low TS content should be avoided in order to prevent leachate formation during storage 

energy losses may occur due to seepage of eventual liquid effluent production. The use

of cattle manure will increase TS content and reduce leachable methane content, that it may entail. Indeed, no production of liquid effluent was recorded during ensiling of cattle manure with wheat straw (result not shown). These outcomes were considered to be representative of a field scale, as cattle manure was ensiled with a commonly used packing density in agricultural silage.

\subsubsection{Kinetics}

Besides the maximum value of methane produced, kinetics of BMP assays were characterized by the $1^{\text {st }}$-order rate coefficient $(k)$ of biomass degradation, Figure 5 . This parameter is closely linked to the biochemical accessibility of biomass, hence the interest for biomass conservation purposes. Nevertheless, while testing prolonged storage, different inoculum should be used for part of BMP series. Contrary to methane potential value, modifications on inoculum properties have an impact on the rate of biomass degradation during BMP assays. Therefore, an indirect approach was used to analyze evolution of $k$ values during storage, which consisted in only comparing results between different conditions for the same storage period (BMP tests were performed 508 with the same inoculum).

509 Concerning the feedstocks, higher rate coefficient was found for fresh cattle manure, 510 being the decrease of biochemical accessibility proportional to the amount of wheat

511 straw added. This confirms that the majority of wheat straw VS was hardly reachable,

512 which was previously suggested by the increase of cellulose content and particulate 513 phase of BMP related to straw addition. 
514 Storage method had a significant effect on biochemical accessibility of fresh cattle

515 manure. In the first 30 days of storage, the difference between the rate coefficients of

516 the two methods progressively increased, benefiting ensiling. This must have been an

517 outcome of: in first place, the degradation of structural carbohydrates into VFA and

518 their accumulation during this period for TS13\%E and; secondly, the important loss of

519 water-soluble compounds in the first month of open-air storage. This scenario was

520 reversed in the last 3 months and the degradation rate of ensiled cattle manure became

521 weaker than the one for the aerobic treatment. On the one hand, this difference cannot

522 be attributed to an increase of the biochemical accessibility for the open-air stored

523 feedstock, since its BMP declined significantly in this period and its water-soluble

524 fraction did not increase. This means that the shift should have been a consequence of

525 VFA degradation for TS13\%E, which led, in addition to the energy damaging, to a great

526 loss of accessibility of the organic matter during the 3 last months of storage.

527 Despite different initial values, similar rate coefficients were obtained for TS19\%E and

528 TS22\%E from 7 days of storage. Furthermore, both conditions with wheat straw

529 presented lower $k$ than TS13\%E until 30 days of ensiling. This was explained by the

530 fact that wheat straw led to a more controlled fermentation, and as formerly discussed to

531 scarcer gains related to the BMP kinetics. At the end of storage, TS19\%E and TS22\%E

532 had far higher degradation rates during the BMP assays than ensiling of fresh cattle

533 manure. This evidenced that wheat straw is an asset on the conservation of great rates of

534 biochemical accessibility for extended periods of ensiling. Restricted fermentation and

535 VFA accumulation in water-soluble phase appear to be the key factors for the success of

536 co-silages with cattle manure and wheat straw. 


\section{Conclusions}

538 Ensiling led to lower energetic losses and $\mathrm{NH}_{3}$ emissions than open-air storage during

539 conservation of cattle manure. Yet, chemical properties of fresh cattle manure hindered

540 silage stabilization for extended periods. Co-ensiling of cattle manure with wheat straw

541 enhanced biomass acidification, inducing a preservation of more than $86 \%$ of methane

542 potential after 4 months. In addition, wheat straw suppressed ammonia production and

543 limited the risks of energy losses through liquid effluent. In summary, this work

544 demonstrated that long-term conservation of cattle manure can be achieved if correct

545 management practices are used. This will impact the performance of agricultural biogas

546 plants.

\section{Acknowledgements}

548 Rúben Teixeira Franco held a doctoral fellowship from the Rhône-Alpes region. This work has been undertaken within the SAM project (Stockage Avant Méthanisation Storage Before AD) funded by ADEME (\# 1506C0038). The authors thank the DEEP laboratory team, including David Lebouil, Hervé Perier-Camby, Nathalie Dumont and Richard Poncet for the given support during the tests. We are grateful to Franck Barra for his permanent availability for discussion and raw material supply. Mathilde Hardier and SUEZ are also acknowledged for the inoculum provided for the BMP tests.

References

556 [1] A. Degueurce, J. Capdeville, C. Perrot, T. Bioteau, J. Martinez, P. Peu, Fumiers de bovins, une ressource à fort potentiel pour la filière de méthanisation en France ?, Sci. Eaux Territ. 24 (2016) 1-9. before biogas production: impact of ensiling and wilting under unsuitable 
weather conditions, Biomass and Bioenergy. 100 (2017) 84-91. doi:10.1016/j.biombioe.2017.03.017.

563 [3] R. Teixeira Franco, P. Buffière, R. Bayard, Optimizing agricultural wastes storage before anaerobic digestion : impact of ensiling on methane potential of lignocellulosic biomass, in: 4th Int. Conf. Sustain. Solid Waste Manag., Limassol, Cyprus, 2016. http://uest.ntua.gr/cyprus2016/proceedings/pdf/RTeixeira_Franco_et_al_Optimizing_agricultural_wastes_storage_before_anaerobic_digestion.pdf.

[4] W. Berg, I. Pazsiczki, Mitigation of methane emissions during manure storage, Int. Congr. Ser. 1293 (2006) 213-216. doi:10.1016/j.ics.2006.02.050.

[6] P. McDonald, A.. Henderson, S.J.. Heron, The Biochemistry of Silage, Second

[5] R. Egg, C. Coble, C. Engler, D. Lewis, Feedstock storage, handling and processing, Biomass and Bioenergy. 5 (1993) 71-94. Edi, Chalcombe Publications, Marlow, Bucks, 1991.

[7] R. Teixeira Franco, P. Buffière, R. Bayard, Ensiling for biogas production: Critical parameters. A review, Biomass and Bioenergy. 94 (2016) 94-104. doi:10.1016/j.biombioe.2016.08.014.

[8] Z.G. Weinberg, G. Ashbell, Engineering aspects of ensiling, Biochem. Eng. J. 13 (2003) 181-188.

[9] C. Herrmann, M. Heiermann, C. Idler, Effects of ensiling, silage additives and storage period on methane formation of biogas crops, Bioresour. Technol. 102 (2011) 5153-5161. doi:10.1016/j.biortech.2011.01.012. 
[10] E. Kreuger, I. Nges, L. Björnsson, Ensiling of crops for biogas production: effects on methane yield and total solids determination, Biotechnol. Biofuels. 4 (2011) 44. doi:10.1186/1754-6834-4-44.

[11] M.G. Porter, R.S. Murray, The volatility of components of grass silage on oven drying and the inter-relationship between dry-matter content estimated by different analytical methods, Grass Forage Sci. 56 (2001) 405-411. doi:10.1046/j.1365-2494.2001.00292.x.

[12] P.J. Van Soest, R.H. Wine, Use of detergents in the analysis of fibrous feeds IV. Determination of plant cell-wall constituents, J. Assoc. Off. Anal. Chem. 50 (1967) 50-55.

[13] C. Holliger, M. Alves, D. Andrade, I. Angelidaki, S. Astals, U. Baier, et al., Towards a standardization of biomethane potential tests, Water Sci. Technol. 74 (2016) 2515-2522. doi:10.2166/wst.2016.336.

[14] P. Kalač, The required characteristics of ensiled crops used as a feedstock for biogas production: a review, J. Agrobiol. 28 (2011) 85-96. doi:10.2478/s10146011-0010-y.

[15] X. Liu, R. Bayard, H. Benbelkacem, P. Buffière, R. Gourdon, Evaluation of the correlations between biodegradability of lignocellulosic feedstocks in anaerobic digestion process and their biochemical characteristics, Biomass and Bioenergy. 81 (2015) 534-543. doi:10.1016/j.biombioe.2015.06.021.

[16] H.D.S.C. Neal, J.H.M. Thornley, A model of the anaerobic phase of ensiling, Grass Forage Sci. 38 (1983) 121-134. doi:10.1111/j.1365-2494.1983.tb01630.x. 
605

606

607

608

609

610

611

612

613

614

615

616

617

618

619

620

621

622

623

624

625

626

[17] R.E. Pitt, R.E. Muck, R.Y. Leibensperger, A quantitative model of the ensilage process in lactate silages, Grass Forage Sci. 40 (1985) 279-303. doi:10.1111/j.1365-2494.1985.tb01755.x.

[18] D.J. Batstone, J. Keller, I. Angelidaki, S. V. Kalyuzhnyi, S.G. Pavlostathis, A. Rozzi, et al., The IWA Anaerobic Digestion Model No 1 (ADM1), Water Sci. Technol. 45 (2002) 65-73. doi:10.2166/wst.2008.678.

[19] S.A.Z. Mahmoud, M.M. Zaki, E.A. Saleh, Factors affecting the microbial and chemical composition of silage: IV. Effect of wilting on maize silage, Zentralblatt Fuer Bakteriol. Parasitenkunde, Infekt. Und Hyg. Zweite Naturwissenschaftliche Abteilung Mikrobiol. Der Landwirtschaft, Der Technol. Und Des Umweltschutzes. 134 (1979) 34-39. doi:10.1016/S03236056(79)80061-0.

[20] J.M. Wilkinson, A laboratory evaluation of comfrey (Symphytum officinale L.) as a forage crop for ensilage, Anim. Feed Sci. Technol. 104 (2003) 227-233.

[21] A. Lehtomäki, Biogas Production from Energy Crops and Crop Residues, Academic dissertation, Department of Biological and Environmental Science, University of Jyväskylä (2006).

[22] O. Pakarinen, A. Lehtoma, S. Rissanen, J. Rintala, Storing energy crops for methane production: Effects of solids content and biological additive, Bioresour. Technol. 99 (2008) 7074-7082. doi:10.1016/j.biortech.2008.01.007.

[23] S. Ghosh, M.P. Henry, R.W. Christopher, Hemicellulose conversion by anaerobic digestion, Biomass. 6 (1985) 257-269. doi:10.1016/0144-4565(85)90052-6. 
640

641

642

643

644

645

646

647

[24] C. Manyi-Loh, S. Mamphweli, E. Meyer, G. Makaka, M. Simon, A. Okoh, An Overview of the Control of Bacterial Pathogens in Cattle Manure, Int. J. Environ. Res. Public Health. 13 (2016) 843. doi:10.3390/ijerph13090843.

[25] E. Marañón, L. Castrillón, J.J. Fernández, Y. Fernández, A.I. Peláez, J. Sánchez, Anaerobic mesophilic treatment of cattle manure in an upflow anaerobic sludge blanket reactor with prior pasteurization, J. Air Waste Manage. Assoc. 56 (2006) 137-143. doi:10.1080/10473289.2006.10464448.

[26] B. Bastiman, Factors affecting silage effluent production, Exp. Husb. 31 (1976) $40-46$.

[27] A. Sutter, Problem of waste effluent from silage making and feeding of silage, Eur. Product. Agency Organ. Eur. Econ. Co-Operation. 307 (1957) 74-82.

[28] E. Zimmer, Efficient silage systems, in: C. Thomas (Ed.), Forage Conserv. 80's, British Grassland Society, Brighton, UK, 1980: pp. 186-197. 
648 Table 1 - Storage conditions

\begin{tabular}{ccccc}
\hline Condition & TS13\%A & TS13\%E & TS19\%E & TS22\%E \\
\hline Approach & Open-air & Ensiling & Ensiling & Ensiling \\
\hline Wheat straw (\%wt) & - & - & $8.3 \%$ & $13.3 \%$ \\
\hline TS (\%wt) & & $12.8 \pm 0.1$ & $18.8 \pm 0.4$ & $22.4 \pm 0.8$ \\
\hline VS (\%wt) & & $10.2 \pm 0.1$ & $15.9 \pm 0.3$ & $17.9 \pm 0.7$ \\
\hline
\end{tabular}

649

650

651

652

653

654

655

656

657

658

659

660

661

662

663

664 
Table 2 - Chemical characteristics of biomass over storage time (\% $\left.\mathrm{VS}_{\text {added/original }}\right)$

\begin{tabular}{|c|c|c|c|c|c|c|c|c|c|c|}
\hline \multirow[b]{2}{*}{ Condition } & \multirow{2}{*}{$\begin{array}{c}\text { Storage } \\
\text { duration } \\
\text { (days) }\end{array}$} & \multicolumn{9}{|c|}{ Chemical characteristics $^{\mathrm{a}}$} \\
\hline & & $\mathrm{pH}$ & $\mathrm{LA}^{\mathrm{b}}$ & $\mathrm{AA}^{\mathrm{b}}$ & $\mathrm{BA}^{\mathrm{b}}$ & $\mathrm{VFA}^{\mathrm{b}}$ & $\mathrm{WSC}^{\mathrm{b}}$ & $\mathrm{HEM}^{\mathrm{c}}$ & $\mathrm{CEL}^{\mathrm{c}}$ & $\mathrm{LIG}^{\mathrm{c}}$ \\
\hline \multirow{5}{*}{ TS13\%A } & 0 & 7.9 & 0.0 & 1.3 & 0.3 & 2.1 & 0.0 & 32.5 & 26.8 & 6.1 \\
\hline & 7 & 7.8 & 0.0 & 1.0 & 0.3 & 1.7 & 0.0 & 26.4 & 22.5 & 8.1 \\
\hline & 14 & 7.9 & 0.0 & 0.9 & 0.4 & 2.0 & 0.0 & 24.8 & 26.1 & 5.5 \\
\hline & 30 & 8.6 & 0.0 & 0.9 & 0.6 & 2.2 & 0.0 & 20.4 & 20.6 & 5.2 \\
\hline & 120 & 9.8 & 0.0 & 0.0 & 0.0 & 0.0 & 0.0 & 13.3 & 10.3 & 5.7 \\
\hline \multirow{5}{*}{ TS13\%E } & 0 & 7.9 & 0,0 & 1.3 & 0.3 & 2.1 & 0.0 & 32.5 & 26.8 & 6.1 \\
\hline & 7 & 7.3 & 0,0 & 1.6 & 0.5 & 3.0 & 0.0 & 30.0 & 26.6 & 6.3 \\
\hline & 14 & 6.9 & 0,1 & 2.8 & 1.1 & 6.0 & 0.0 & 26.5 & 24.9 & 5.8 \\
\hline & 30 & 6.9 & 0,0 & 6.7 & 2.2 & 12.9 & 0.0 & 24.0 & 20.3 & 6.2 \\
\hline & 120 & 8.4 & 0,0 & 1.1 & 0.0 & 1.7 & 0.0 & 16.7 & 16.9 & 6.1 \\
\hline \multirow{5}{*}{ TS19\%E } & 0 & 8.3 & 0,0 & 1.1 & 0.2 & 1.8 & 0.0 & 28.7 & 36.0 & 6.1 \\
\hline & 7 & 7.2 & 0,0 & 2.3 & 0.5 & 3.6 & 0.0 & 26.6 & 33.4 & 6.6 \\
\hline & 14 & 6.5 & 0,1 & 2.5 & 1.0 & 4.8 & 0.0 & 24.8 & 32.1 & 5.1 \\
\hline & 30 & 5.6 & 0.0 & 4.1 & 3.0 & 9.4 & 0.0 & 24.5 & 30.2 & 5.3 \\
\hline & 120 & 5.5 & 0.0 & 7.4 & 4.2 & 15.7 & 0.0 & 22.0 & 24.8 & 4.6 \\
\hline \multirow{5}{*}{ TS22\%E } & 0 & 8.2 & 0.0 & 1.1 & 0.1 & 1.8 & 0.0 & 27.5 & 37.2 & 6.3 \\
\hline & 7 & 6.8 & 0.0 & 2.0 & 0.4 & 3.1 & 0.0 & 26.9 & 36.7 & 5.9 \\
\hline & 14 & 6.2 & 0.0 & 2.1 & 0.9 & 4.0 & 0.0 & 27.1 & 35.8 & 5.4 \\
\hline & 30 & 5.5 & 0.0 & 3.3 & 2.4 & 7.5 & 0.1 & 27.3 & 30.8 & 7.0 \\
\hline & 120 & 5.4 & 0.0 & 6.3 & 4.8 & 15.5 & 0.0 & 21.9 & 24.8 & 7.2 \\
\hline
\end{tabular}

${ }^{\mathrm{a}}$ LA stands for Lactic Acid, AA for Acetic Acid, BA for Butyric Acid, HEM for Hemicellulose, CEL for Cellulose and, LIG for Lignin; ${ }^{\mathrm{b}}$ results based on $\% \mathrm{VS}_{\text {added }} ;{ }^{\mathrm{c}}$ results based on $\% \mathrm{VS}_{\text {original }}$ 
(A)

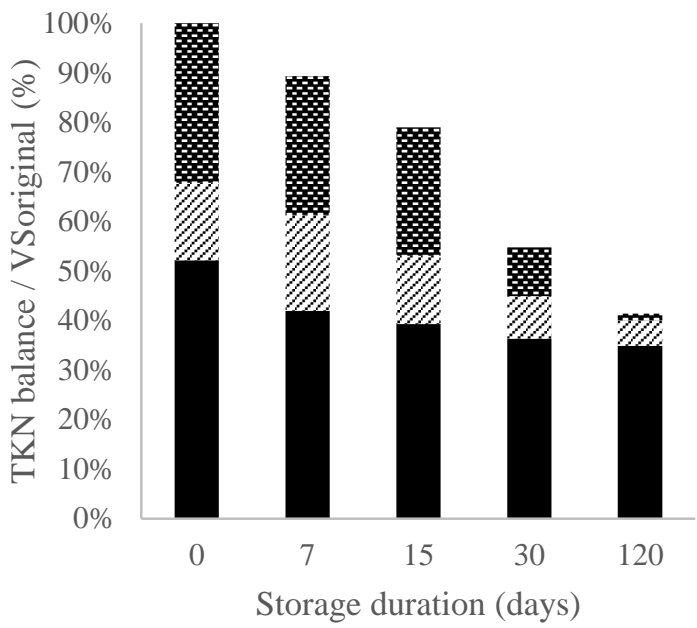

Water-soluble: NH4 2 Water-soluble: Other - Particulate

(C)

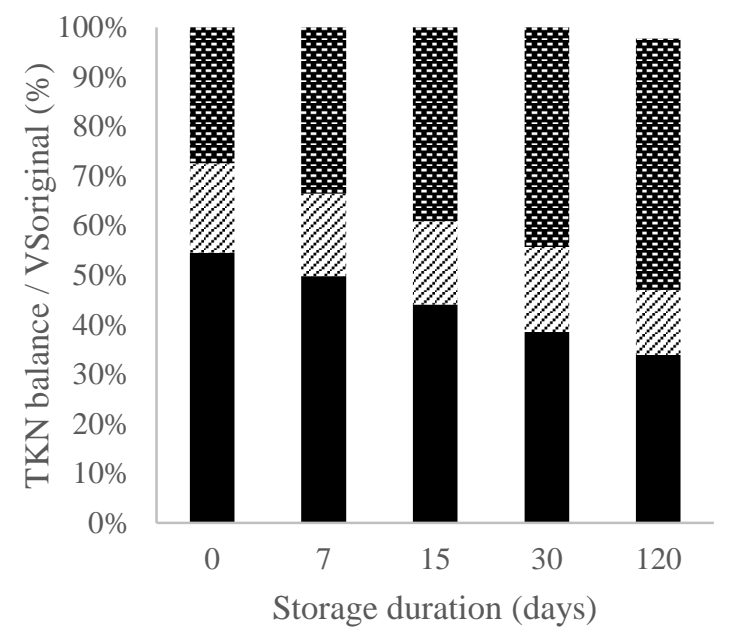

Water-soluble: NH4 « Water-soluble: Other - Particulate
(B)

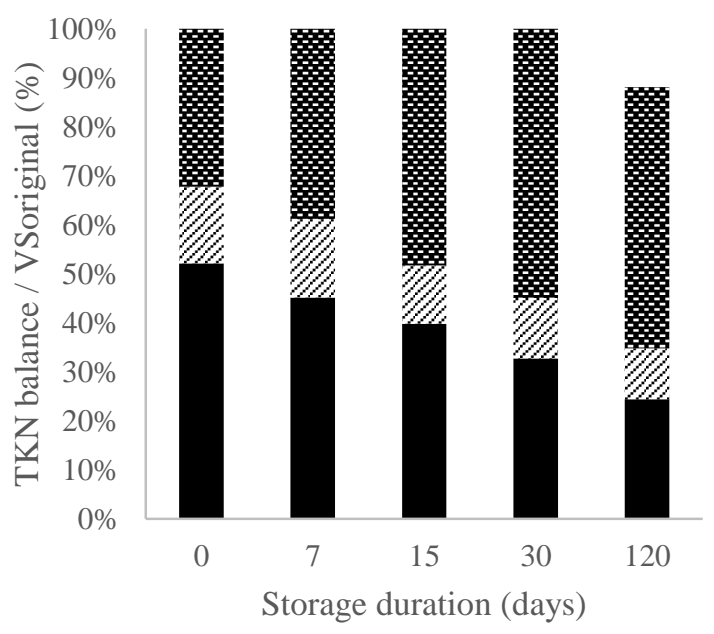

異 Water-soluble: NH4 «Water-soluble: Other - Particulate

(D)

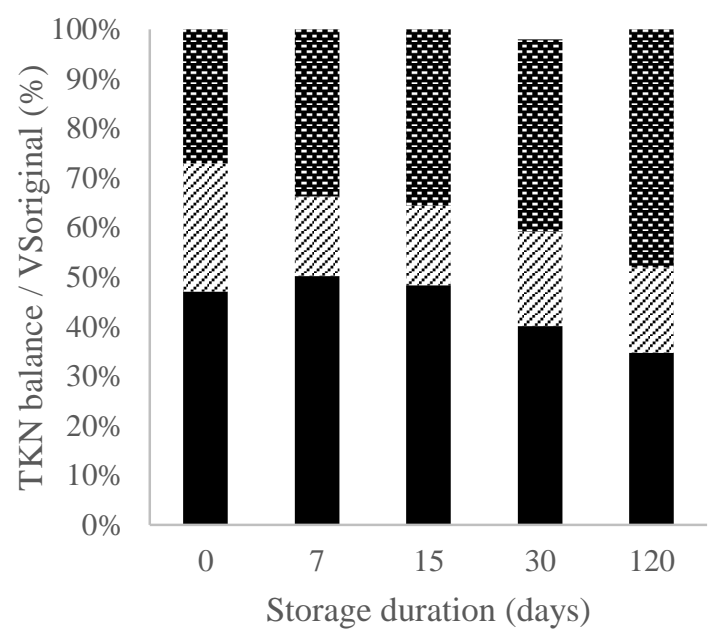

Water-soluble: NH4 \% Water-soluble: Other - Particulate

676 Figure 1 - TKN balance for: (A) TS13\%A; (B) TS13\%E; (C) TS19\%E; (D) TS22\%E

677

678

679 


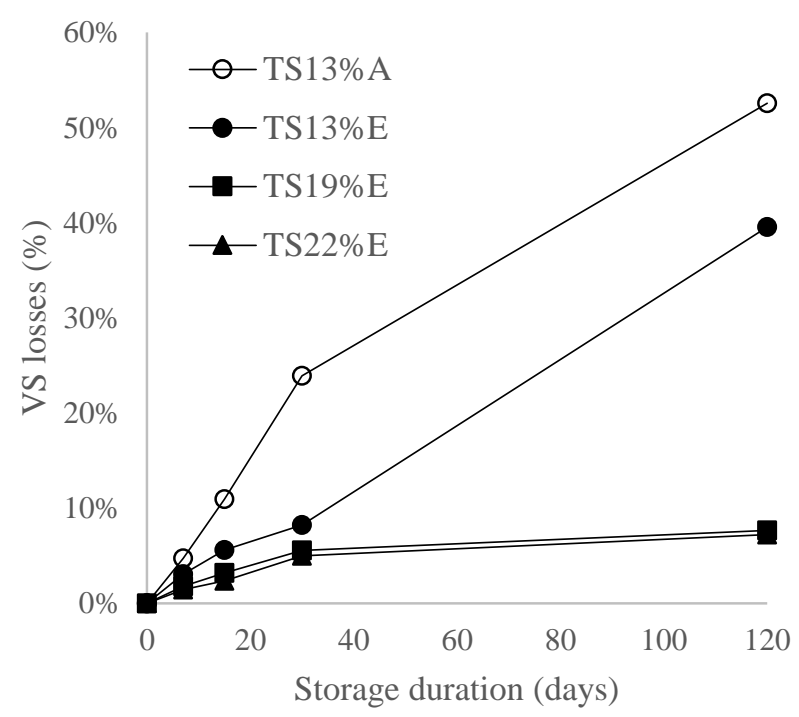

681

682 Figure 2 - Organic matter losses over storage duration

683

684

685

686

687

688

689

690

691

692

693

694 
(A)

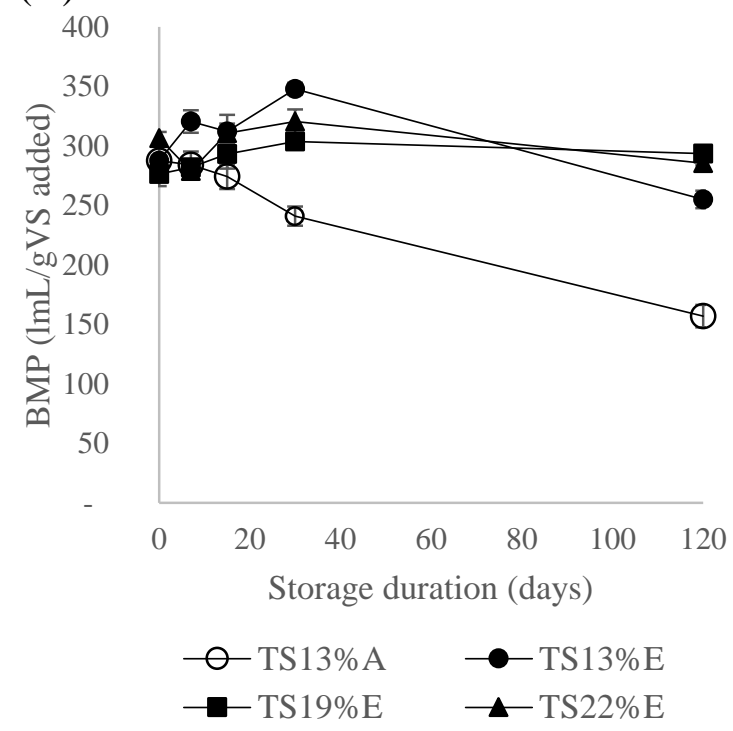

(B)

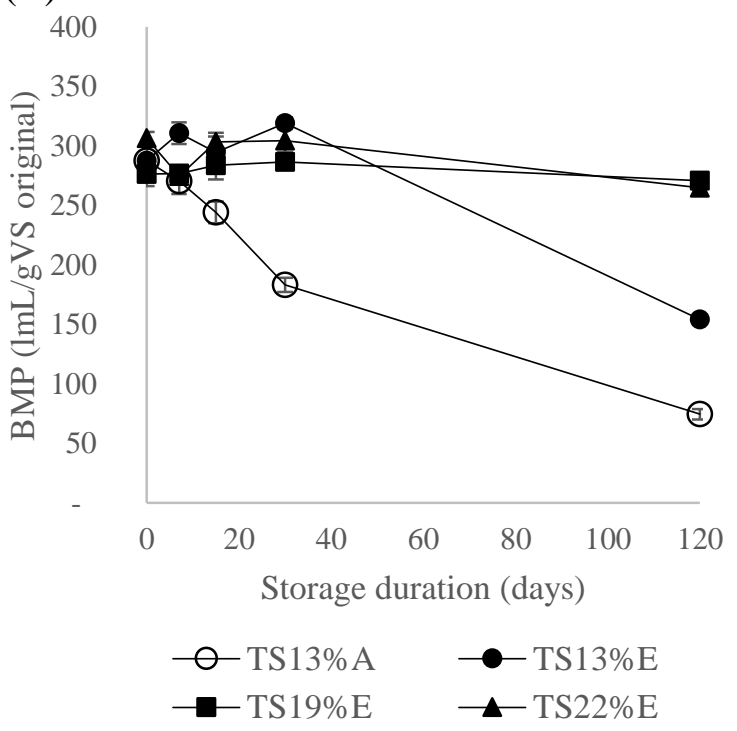

698

699

700

701

702

703

704

705

706

707

05

Figure 3 - Global BMP evolution over storage duration. (A): methane potential based on $\mathrm{VS}_{\text {added}}$; (B): methane potential based on $\mathrm{VS}_{\text {original, }}$, therefore considering storage losses. .

8

\section{9}


(A)

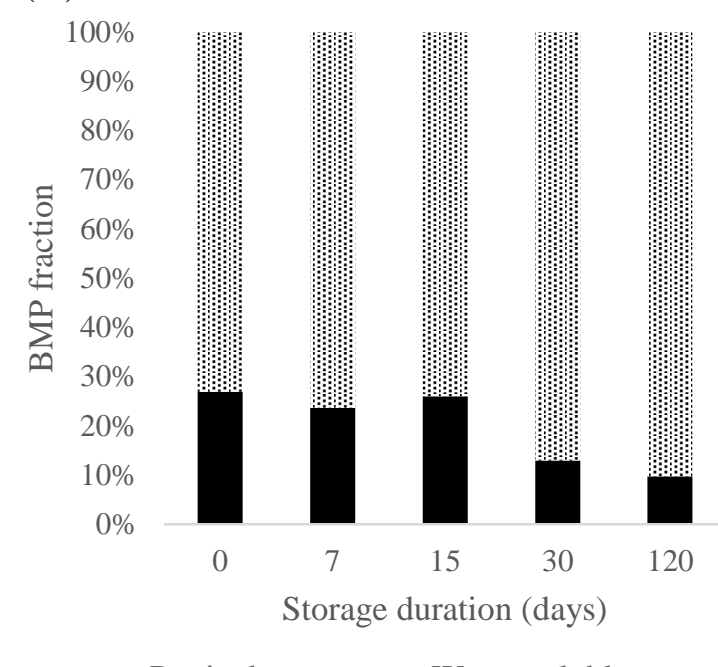

mP Particulate $\quad$ Water-soluble

(C)

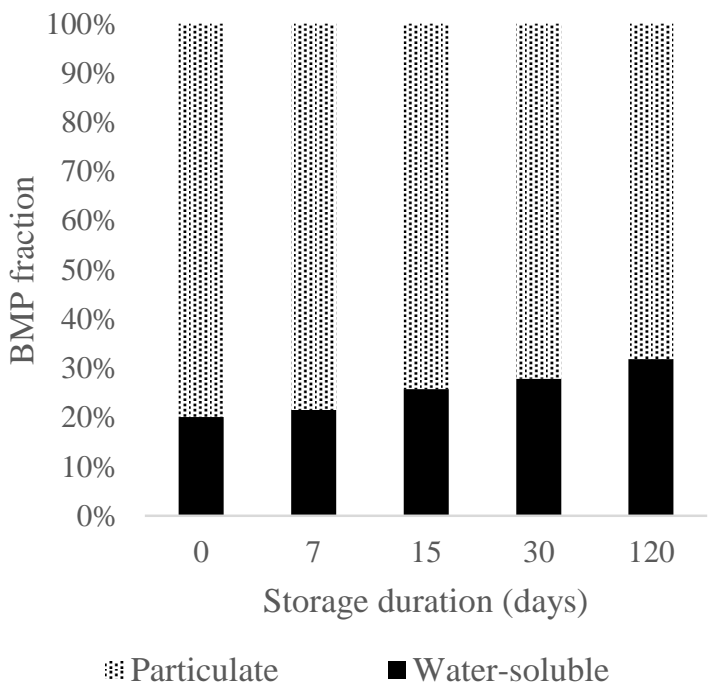

(B)

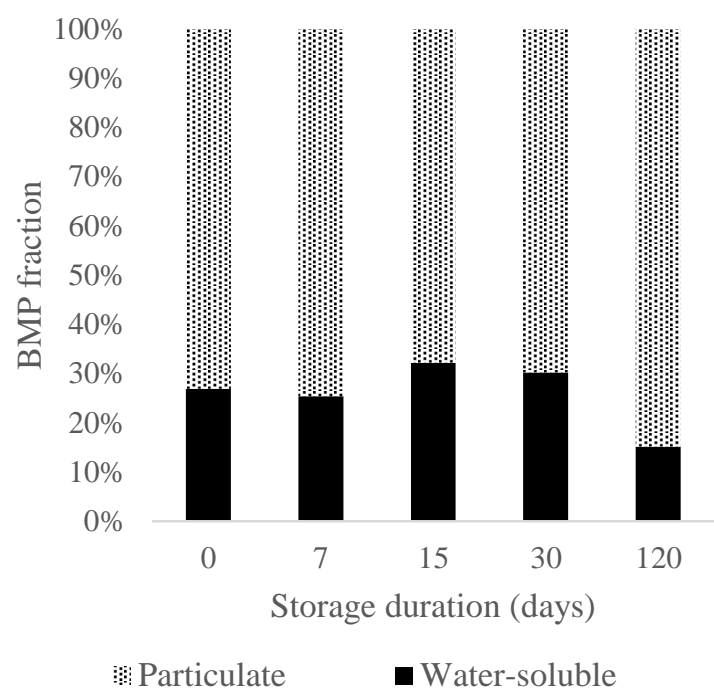

(D)

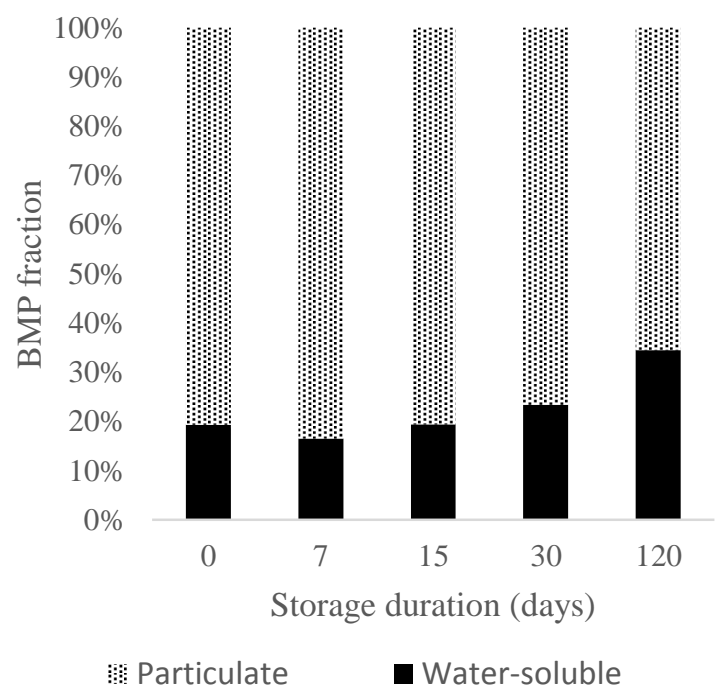

Figure 4 - BMP multi-phase analysis for: (A) TS13\%A; (B) TS13\%E; (C) TS19\%E; (D) $\mathrm{TS} 22 \% \mathrm{E}$ 


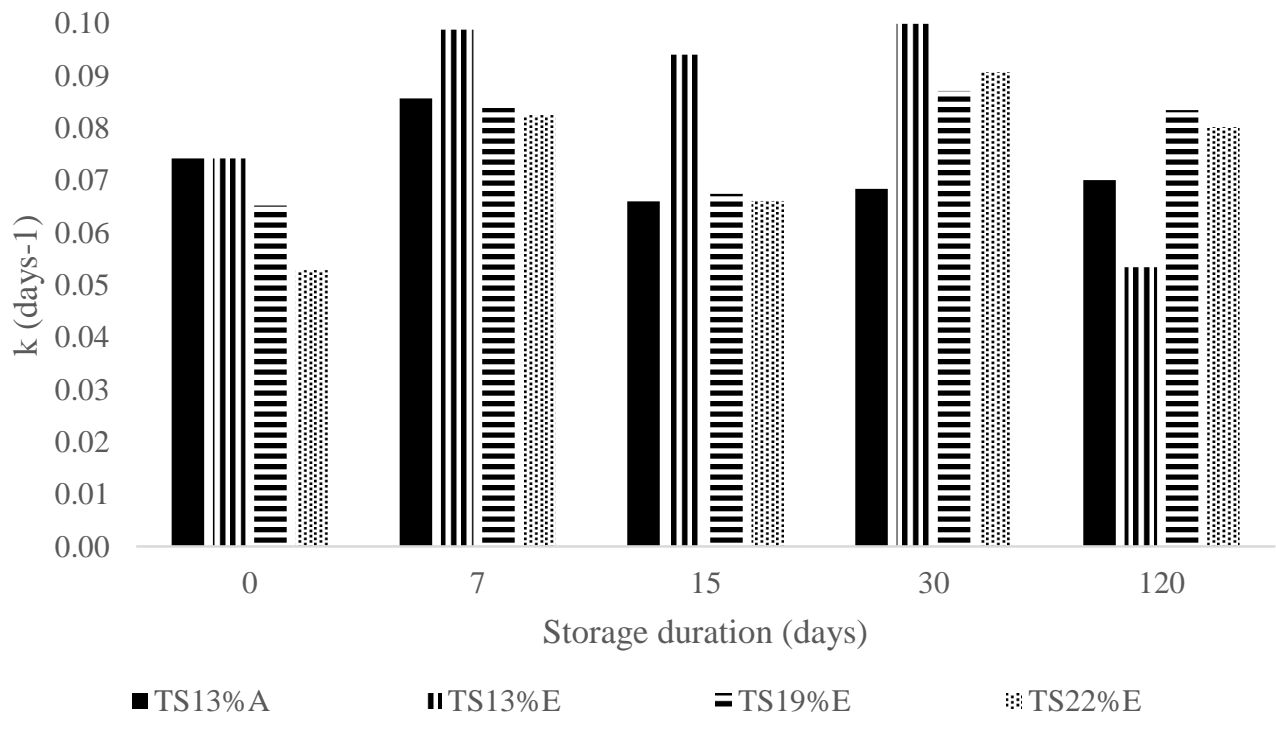

716 Figure 5 - Rate coefficient $(k)$ of BMP assays over storage time. Standard deviations are 717 not presented as differences among triplicates were negligible. 